\title{
Systematics of the Oswaldoi Complex (Anopheles, Nyssorhynchus) in South America
}

\author{
Freddy Ruiz-Lopez ${ }^{1,2^{*}}$, Richard C Wilkerson ${ }^{1,3}$, David J Ponsonby ${ }^{4}$, Manuela Herrera ${ }^{5}$, Maria Anice Mureb Sallum ${ }^{6}$, \\ Ivan Dario Velez ${ }^{2}$, Martha L Quiñones ${ }^{5}$, Carmen Flores-Mendoza ${ }^{7}$, Dave D Chadee ${ }^{8}$, Joubert Alarcon ${ }^{9}$, \\ Joubert Alarcon-Ormasa ${ }^{9}$ and Yvonne-Marie Linton ${ }^{3,10}$
}

\begin{abstract}
Background: Effective malaria control relies on accurate identification of those Anopheles mosquitoes responsible for the transmission of Plasmodium parasites. Anopheles oswaldoi s.l. has been incriminated as a malaria vector in Colombia and some localities in Brazil, but not ubiquitously throughout its Neotropical range. This evidence together with variable morphological characters and genetic differences supports that An. oswaldoi s.l. compromises a species complex. The recent fully integrated redescription of An. oswaldoi s.s. provides a solid taxonomic foundation from which to molecularly determine other members of the complex.

Methods: DNA sequences of the Second Internal Transcribed Spacer (ITS2 - rDNA) $(n=192)$ and the barcoding region of the Cytochrome Oxidase I gene (COI - mtDNA) $(n=110)$ were generated from 255 specimens of An. oswaldoi s.l. from 33 localities: Brazil (8 localities, including the lectotype series of An. oswaldoi), Ecuador (4), Colombia (17), Trinidad and Tobago (1), and Peru (3). COl sequences were analyzed employing the Kimura-two-parameter model (K2P), Bayesian analysis (MrBayes), Mixed Yule-Coalescent model (MYC, for delimitation of clusters) and TCS genealogies.

Results: Separate and combined analysis of the COI and ITS2 data sets unequivocally supported four separate species: two previously determined (An. oswaldoi s.s. and An. oswaldoi B) and two newly designated species in the Oswaldoi Complex (An. oswaldoi A and An. sp. nr. konderi). The COI intra- and inter-specific genetic distances for the four taxa were non-overlapping, averaging 0.012 (0.007 to 0.020) and 0.052 (0.038 to 0.064), respectively. The concurring four clusters delineated by MrBayes and MYC, and four independent TCS networks, strongly confirmed their separate species status. In addition, An. konderi of Sallum should be regarded as unique with respect to the above. Despite initially being included as an outgroup taxon, this species falls well within the examined taxa, suggesting a combined analysis of these taxa would be most appropriate.

Conclusions: Through novel data and retrospective comparison of available COI and ITS2 DNA sequences, evidence is shown to support the separate species status of An. oswaldoi s.S., An. oswaldoi A and An. oswaldoi B, and at least two species in the closely related An. konderi complex (An. sp. nr. konderi, An. konderi of Sallum). Although An. oswaldoi s.s. has never been implicated in malaria transmission, An. oswaldoi B is a confirmed vector and the new species An. oswaldoi A and An. sp. nr. konderi are circumstantially implicated, most likely acting as secondary vectors.
\end{abstract}

Keywords: Anopheles oswaldoi species complex, An. oswaldoi s.S., An. oswaldoi A, An. oswaldoi B, An. sp. nr. konderi, COl barcoding, ITS2

\footnotetext{
* Correspondence: fredyruiz9@gmail.com

${ }^{1}$ Department of Entomology, National Museum of Natural History,

Smithsonian Institution, Museum Support Center, Suitland, MD 20746, USA

${ }^{2}$ Programa de Estudio y Control de Enfermedades Tropicales (PECET),

Facultad de Medicina, Universidad de Antioquia, Medellín, Colombia

Full list of author information is available at the end of the article
}

\section{Biomed Central}

(c) 2013 Ruiz-Lopez et al.; licensee BioMed Central Ltd. This is an open access article distributed under the terms of the Creative Commons Attribution License (http://creativecommons.org/licenses/by/2.0), which permits unrestricted use, distribution, and reproduction in any medium, provided the original work is properly cited. 


\section{Background}

Species complexes are relatively common in the family Culicidae [1], and several Neotropical Anopheles, including some vector species, are known to comprise isomorphic species. Within the Oswaldoi Group alone (Anopheles, subgenus Nyssorhynchus), seven of the 15 formally recognised species comprise complexes [2-11]. Anopheles oswaldoi (Peryassú) is one such taxon. It is thought to comprise a species complex in Brazil [4,9,12-16] and Colombia $[8,13,17]$ and has been implicated in malaria transmission in some parts of its range [11-13], yet its taxonomic and vectorial status elsewhere in South America remains unclear. A comprehensive revision of the taxonomy and current distribution of An. oswaldoi is given in Motoki et al. [12].

Several studies have provided evidence for genetic variation in An. oswaldoi. Firstly, Marrelli et al. [14] analyzed ITS2 sequences from seven populations of An. oswaldoi s.l. and determined four geographic groups, as follow: Group I from Acre, Amazonas and Rondônia (Brazil), Group II from Ocamo (Venezuela) and Amapá (Brazil), Group III from Espírito Santo (type locality), Brazil and Group IV from Yurimaguas, Peru. Subsequently, Ruiz et al. [17] revised these groupings and determined that Group II corresponded to An. oswaldoi B from Putumayo, Colombia [13], and that Group IV from Yurimaguas, Peru, was actually An. benarrochi B [17], a newly recognized species of the subgenus Nyssorhynchus [17,18]. The identification of Group III (GenBank: AF055072) from the type locality of Espírito Santo in Brazil was later corrected to that of An. evansae (Bréthes) [4]. The misidentification resulted from the incorrect use of polymorphic characters in the wing (humeral pale spot) and second hindtarsal segment (basal dark band); characters that overlap between An. oswaldoi and An. evansae in currently available taxonomic keys [11]. The true identity of Group I remains unclear.

Scarpassa and Conn [16] sequenced a long fragment of COI from 45 An. oswaldoi s.l. from four populations from Brazil (Acre, Amazonas, Rondônia and Pará). Parsimony analysis revealed four distinct groups: Group I, Acre (Sena Madeira) and Rondônia (São Miguel); Group II, Rondônia (São Miguel); Group III, Pará (Moju), and Group IV from Acre (Sena Madureira) and Coari (Amazonas). Although the authors tentatively suggested that Group I may be An. oswaldoi s.s. and Group IV may be An. konderi Galvão and Damasceno, based primarily on geographic origin, they lacked certainty in assigning taxonomic names to these phylogenetic lineages.

The taxonomic confusion between An. oswaldoi and An. konderi is not new. Anopheles konderi was originally described from specimens collected in the Solimões River at Coari, Amazonas, Brazil in 1942 [19]. Soon after, Lane [20] reduced it to a junior synonym of $A n$. oswaldoi, where it remained until its re-elevation to separate species status in 2004 [21]. Isoenzyme analysis of 20 loci in three populations of purported An. oswaldoi and An. konderi from the Brazilian Amazon (Coari, Amazonas (An. konderi); São Miguel, Rondônia (An. oswaldoi and An. konderi) and Sena Madureira, Acre (An. oswaldoi and An. konderi)) revealed no significant differences between populations, and led the author to question whether An. oswaldoi and $A n$. konderi were indeed truly separate species, or whether ongoing introgression between the two species would explain this low level of variation [22]. Recently, Motoki et al. [23] using COI, white and ITS2 DNA sequences confirmed that morphologically identified specimens of An. konderi comprised at least three species in the Amazonian region. Unfortunately, none of these recent studies (including the redescription [21]) have examined specimens from the type locality, thus the true identity of An. konderi s.s. remains unclear.

The same was true for An. oswaldoi s.s. until a recent redescription of the species was undertaken based on progeny broods collected from the type locality of Espírito Santo, Brazil [12]. This study included morphological data for immature stages (fourth-instar larvae and pupae) and adults of both sexes, as well as corresponding ITS2 DNA sequence. As a holotype was not designated for An. oswaldoi s.s. when it was first described by Peryassú in 1922, a lectotype was chosen from the type series [12]. This study provided a solid taxonomic platform from which to attempt to further determine the component members of the Oswaldoi Complex. Comparison of DNA sequences of An. oswaldoi s.s. [12] confirms that neither Marrelli et al. [14] (ITS2), nor Scarpassa and Conn [16] (COI) included "true" An. oswaldoi in their studies. To date, An. oswaldoi s.s. has only been confirmed in the Brazilian States of Espírito Santo, Rio de Janeiro and São Paulo in Brazil [12,24]. Pinault and Hunter [25] recently reported three COI sequences of An. oswaldoi from Ecuador (GenBank: JN412831-33), however these sequences were misidentified, sharing high similarity with those of An. rangeli (GenBank: HM022390-94). Based on morphology and ITS2 sequences, Sallum et al. [9] detected at least two cryptic species in An. oswaldoi s.l. collected in the state of Acre (Brazil), both of which differ from An. oswaldoi s.s.

Given the evidence above, there is no doubt that An. oswaldoi comprises a species complex in Latin America. The objectives of this study were to ascertain the taxonomic status and relative distribution of the component members of the An. oswaldoi species complex in Brazil, Colombia, Ecuador, Peru, Trinidad and Tobago and Venezuela using ITS2 and COI barcodes, and to correlate this information with previously documented vector incrimination studies of $A n$. oswaldoi s.l. across its range. 


\section{Methods}

\section{Specimens}

A total of 255 specimens of Anopheles oswaldoi s.l. from 33 localities in five countries in the Neotropics (Brazil, Colombia, Ecuador, Peru and Trinidad and Tobago) were used in this study (see Table 1 for georeferenced locality data). Co-ordinates were converted to decimal degrees [26] and the distribution data is available in Mosquito Map (www.mosquitomap.org). Samples of Anopheles konderi s.l. were collected near Macapá, Amapá, Brazil and identified on the basis of the male aedeagus by MAMS. To avoid confusion, these are referred to herein as An. konderi of Sallum. All specimens used in this study were collected or provided by the authors of this study.

\section{Molecular analysis}

DNA was extracted using the DNeasy ${ }^{\odot}$ Blood and Tissue Kit (QIAgen ${ }^{\oplus}$, USA) on the automated BioSprint $96^{\circ}$ robotic platform. The ITS2 region was amplified for 192 samples from 21 localities using the published primers

Table 1 Origin and georeferences of An. oswaldoi s.l. specimens used in this study, showing relative numbers of COI $(n=110)$ and ITS2 $(n=192)$ sequences obtained from 255 specimens have been used

\begin{tabular}{|c|c|c|c|c|c|c|}
\hline Country & State and exact locality & $\mathrm{n}=$ & $\mathrm{COI}$ & ITS2 (H) & Latitude & Longitude \\
\hline \multirow[t]{8}{*}{ Brazil } & Amazonas, Tefé & 1 & 1 & $1(\mathrm{III})$ & -03.3207 & -64.7236 \\
\hline & Espirito Santo, Jaguaré, Fazenda Marianelli & 10 & 3 & $10(1)$ & -19.0348 & -39.9485 \\
\hline & Mato Grosso, Peixoto de Azevedo & 42 & 42 & $14(I I, I V-I X)$ & -10.2257 & -54.9862 \\
\hline & Rio de Janeiro, Morro de Panela & 2 & 2 & - & -22.9678 & $-43.3-415$ \\
\hline & Rondônia, Ariquemes & 3 & 3 & - & -09.9136 & -63.0440 \\
\hline & Rondônia, Costa Marques & 3 & 3 & - & -12.4156 & -64.2215 \\
\hline & São Paulo, Pariquera-Açu & 2 & 2 & $2(I)$ & -24.9875 & -47.9561 \\
\hline & São Paulo, Pariquera-Açu & 1 & 1 & - & -24.7096 & -47.8839 \\
\hline \multirow[t]{17}{*}{ Colombia } & Amazonas, Kilometro 12 & 1 & 1 & $1($ (III) & -04.1159 & -69.9522 \\
\hline & Antioquia, Nechí, Mala Noche & 28 & 12 & $28(X)$ & 08.1101 & -74.7671 \\
\hline & Caquetá, Peñas Coloradas & 2 & 2 & $1(X I I)$ & 00.8699 & -73.8419 \\
\hline & Meta, Granada, Morichal & 2 & 2 & - & 03.5372 & -73.7009 \\
\hline & Norte de Santander, Tibú & 1 & 1 & $1(X)$ & 08.6403 & -72.7371 \\
\hline & Putumayo, Agua Negra & 14 & - & $14(X \mid I)$ & 00.7494 & -75.3834 \\
\hline & Putumayo, Cecilia Cocha & 5 & - & $5(X \|)$ & 00.1158 & -74.9781 \\
\hline & Putumayo, La Apaya & 6 & - & $6(X I I)$ & 00.7494 & -75.3833 \\
\hline & Putumayo, Pto. Asís, Cecilia Cocha & 24 & - & $24(X I I)$ & 00.1158 & -74.9781 \\
\hline & Putumayo, Pto. Asís, La Manuela & 4 & 4 & - & 00.5133 & -76.4992 \\
\hline & Putumayo, Pto. Leguizamo, Bella Vista & 8 & - & $8(X I I)$ & 00.7494 & -75.3833 \\
\hline & Putumayo, Pto. Leguizamo, El Salado & 9 & - & $9(X I I)$ & 00.2108 & -74.8036 \\
\hline & Putumayo, Pto. Leguizamo, La Quebradita & 4 & 4 & $2(X I I)$ & 00.5133 & -76.4992 \\
\hline & Putumayo, Pto. Leguizamo, Lagarto Cocha & 39 & - & $39(X I I)$ & 00.2108 & -74.8036 \\
\hline & Putumayo, Pto. Leguizamo, Puntales & 13 & - & $13(X \mid I)$ & 00.4272 & -74.3986 \\
\hline & Putumayo, Pto. Leguizamo, Tukare & 1 & 1 & $1(X \|)$ & 00.5133 & -76.4992 \\
\hline & Putumayo, Pto. Nariño & 2 & - & $2(X \|)$ & 00.7494 & -75.3833 \\
\hline \multirow[t]{4}{*}{ Ecuador } & Orellana, Coca, Cañon de los Monos & 2 & 2 & - & -00.3434 & -77.0070 \\
\hline & Orellana, Coca, Guamayacu & 4 & 4 & - & 00.1300 & -77.2313 \\
\hline & Orellana, Coca, Juan Montalvo & 7 & 7 & - & -00.4725 & -76.9914 \\
\hline & Orellana, Tiputini & 2 & 2 & - & -00.6381 & -76.1450 \\
\hline \multirow[t]{3}{*}{ Peru } & Loreto, Iquitos & 1 & 1 & - & -03.7561 & -73.2706 \\
\hline & Loreto, Rio Putumayo & 1 & 1 & - & -04.2325 & -74.2179 \\
\hline & Madre de Dios, Davila & 1 & 1 & $1(\mathrm{XIII})$ & -11.7669 & -70.8119 \\
\hline Trinidad and Tobago & Valencia, St. Andrew/St. David & 10 & 8 & $10(\mathrm{XI})$ & 10.6447 & -61.0936 \\
\hline
\end{tabular}


of Collins and Paskewitz [27] and following the protocol in Linton et al. [28]. DNA barcodes [29] were amplified from 110 individuals from 24 localities using the universal barcoding primers developed by Folmer et al. [30] and the protocol of the Mosquito Barcoding Initiative, expressly listed in Ruiz et al. [31].

Sequencing reactions were carried out in both directions using the Big Dye Terminator Kit ${ }^{\circ}$ on an ABI3770 automated sequencer (PE Applied BioSystems ${ }^{\circ}$, Warrington, England). Sequence chromatograms were edited using Sequencher ${ }^{\mathrm{Tm}}$ v. 4.8 (Genes Codes Corporation, Ann Arbor, MI). Sequences were aligned automatically in Mafft Pro 5.5.7 (www.geneious.com) or using MacClade v. 4.06 [32]. Basic Local Alignment Search Tool (BLAST) searches (http://blast.ncbi.nlm.nih.gov) were carried out to correlate our sequences with those publicly available in GenBank.

To assess population-level genealogies, $\mathrm{COI}$ sequences were analyzed using TCS v. 1.21 [33]. A connection limit of $95 \%$ was adopted to investigate whether An. oswaldoi formed a single "meta-population" (reflected by a single network) or is comprised of separate species in South America (reflected by the formation of two or more independent networks).

A COI data matrix was generated in MEGA v. 5 [34]. COI sequences were grouped according to the results of the TCS analysis, and intra- and inter-group genetic distances compared using Kimura's 2-Parameter distance (K2P) algorithm [35]. Phylogenetic analysis was carried out on the separate and combined ITS2 and COI data sets. MrModeltest v. 2.3 [36] was used to choose the best evolutionary model for these regions separately using the Akaike Information Criterion (AIC) search. A partitioned Bayesian analysis (by DNA region) was subsequently performed using MrBayes v. 3.1.2 [37], available online (http://cbsuapps.tc.cornell.edu/mrbayes. aspx).

The analysis in MrBayes ran for 10 million generations with two parallel searches using three heated and one cold Markov chain. The first 5 million generations were discarded as burn-in. Support for this Bayesian tree was conducted by generating a maximum parsimony (MP) tree in PAUP v. 4.0b10 [38] for both ITS2 and COI, and bootstrapping [39], using a heuristic search, simple stepwise addition, TBR branch swapping and 1000 bootstrap replicates.

Unique COI haplotypes were further analysed using MYC [40,41] for delimitation of COI clusters. This method optimizes a threshold age that corresponds to the shift from coalescent to species diversification [42] branching processes and calculates the number of resulting independent entities. The likelihood of the null model that all samples belong to a single species is compared to that of the alternative hypothesis where separate coalescent groups are nested within the species tree. Confidence limits correspond to threshold values $\pm 2 \log \mathrm{L}$ units around the ML estimate. This analysis was conducted on Bayesian consensus trees and each tree was converted to ultrametric using penalized likelihood as implemented in r8s v.1.7 [43], with the optimal smoothing parameter selected by cross-validation of values between 0.01 and 1000. FigTree v. 1.2.1 [44] was used to edit all trees generated.

\section{Results}

Specimens of An. oswaldoi s.l. $(\mathrm{n}=255)$ were obtained from 33 localities in five South American countries as follow (Table 1): Brazil $(\mathrm{n}=64)$, Colombia $(\mathrm{n}=163)$, Ecuador $(\mathrm{n}=15)$, Peru $(\mathrm{n}=3)$ and Trinidad and Tobago $(\mathrm{n}=10)$. From these mosquitoes, 192 ITS2 sequences were generated and a subset of 110 of these, including four specimens from the redescription [12], were also barcoded. The full data sets by country follow: Brazil (27 ITS2; 57 COI, GenBank: KF809034-078, KF809121-132), Colombia (154 ITS2; 27 COI, GenBank: KF809079, KF809085-091, KF809093-096, KF809100, KF809102, KF809105, KF809109-119, KF809133), Ecuador (15 COI, GenBank: KF809081-084, KF809099, KF809103, KF8 09108, KF809120, KF809135-139, KF809142-143), Peru (1 ITS2; 3 COI, GenBank: KF809134, KF809140-141) and Trinidad and Tobago (10 ITS2; 8 COI, GenBank: KF809080, KF809092, KF809097-098, KF809101, KF8 09104, KF809106-107, KF809128). COI sequences of An. konderi sensu Sallum $(\mathrm{n}=4)$ are available in GenBank under accessions KF809030-033.

\section{ITS2 sequences of An. oswaldoi s.l.}

ITS2 sequences were generated for 192 specimens of An. oswaldoi s.l. (Table 1). The overall alignment (544 bp, after primer trim) revealed 13 unique ITS2 haplotypes (GenBank: KC970065-77), labelled HI-HXIII (Table 2). The ITS2 sequences ranged in length from 530 bp in Haplotype I (H1) (Espírito Santo and São Paulo) to $540 \mathrm{bp}$ in haplotypes HVI-IX from Mato Grosso in Brazil (Table 2). Thirty-two variable bases were noted (5.9\%), with the variation concentrated toward the second half ( $3^{\prime}$ end) of the ITS2 fragment between aligned nucleotides 207-494. Indels (insertions/ deletions) were observed at bases 337-338, 344-345, 365-369, 408-409, 416-419, and 467-468 (Table 2).

Whereas in general all geographical areas were represented by unique ITS2 haplotypes, the 14 specimens of An. oswaldoi from Mato Grosso (Brazil) showed seven unique haplotypes (HII, HIV - HIX), varying in length between $538 \mathrm{bp}$ and $540 \mathrm{bp}$ (Table 2). Specimens from Putumayo, Colombia $(\mathrm{n}=123)$ and Caquetá, Colombia $(\mathrm{n}=1)$ shared the same ITS2 haplotype (HXII) and one specimen from Amazonas, Colombia shared the same 
Table 2 Comparative alignment and size differentials of the 13 unique ITS2 haplotypes detected in 192 specimens of An. oswaldoi s.I. from Brazil (BR, $n=27)$, Colombia (CO, $n=154)$, Peru $(P E, n=1)$ and Trinidad and Tobago (TR, $n=10)$ $\begin{array}{llllllllllllllllllllllllllllllll}2 & 2 & 3 & 3 & 3 & 3 & 3 & 3 & 3 & 3 & 3 & 3 & 3 & 3 & 4 & 4 & 4 & 4 & 4 & 4 & 4 & 4 & 4 & 4 & 4 & 4 & 4 & 4 & 4 & 4 & 4 & 4\end{array}$ $\begin{array}{llllllllllllllllllllllllllllllll}0 & 5 & 1 & 3 & 3 & 3 & 4 & 4 & 4 & 6 & 6 & 6 & 6 & 6 & 0 & 0 & 0 & 1 & 1 & 1 & 1 & 1 & 5 & 6 & 6 & 6 & 7 & 7 & 7 & 7 & 8 & 9\end{array}$ $\begin{array}{llllllllllllllllllllllllllllllllllll}\text { Haplptypes } & n & \text { Spicemen origen } & & 7 & 9 & 0 & 2 & 7 & 8 & 2 & 4 & 5 & 5 & 6 & 7 & 8 & 9 & 4 & 8 & 9 & 2 & 6 & 7 & 8 & 9 & 5 & 1 & 7 & 8 & 0 & 3 & 4 & 7 & 6 & 4\end{array}$ $\mathrm{HI} \quad 12$ Espirito Santo/São BR A C A A - A - A - A C C A C - - C A - G - G A C HII 1 Mato Grosso, BR ACTC- $A-$ - A C C A T C A G A A G A A C A - G G C G A HIII 2 Amazonas, BR\& GCTC- $\quad$ \& $-A T C A T C A G A A G A A C A-A G G C G G A$ Amazonas, CO

\begin{tabular}{|c|c|c|c|c|c|c|c|c|c|c|c|c|c|c|c|c|c|c|c|c|c|c|c|c|c|c|c|}
\hline HIV & Mato Grosso, BR & G & $C T$ & $T C$ & - & $-A$ & - & - & A & $C$ & $C$ & $\mathrm{~A}$ & T & $C A$ & $A G$ & $A$ & A & G & $A A$ & $A C$ & $C A$ & - & - & $G C$ & $G C$ & $G$ & G \\
\hline HV & Mato Grosso, BR & G & $C T$ & $T C$ & - & $-A$ & - & - & A & $C$ & $C$ & $A$ & T & $C A$ & $A G$ & $A$ & A & G & $A A$ & $A C$ & $C A$ & - & - & GC & $G C$ & G & A \\
\hline 1 & Mato Grosso, BR & G & C T & $T A$ & - & $-A$ & A & G & $A$ & $C$ & $C$ & $A$ & $\mathrm{~T}$ & $C A$ & $A G$ & $A$ & A & G & $A A$ & $A C$ & $C G$ & - & - & GC & $G C$ & $\mathrm{G}$ & \\
\hline 3 & Mato Grosso, BR & G & C T & T A & - & $-A$ & A & G & A & $\mathrm{T}$ & $C$ & $A$ & T & $C A$ & $A G$ & $A$ & A & G & A $A$ & $A C$ & $C A$ & - & - & G C & $\mathrm{G} C$ & $G_{1}$ & G \\
\hline 1 & Mato Grosso, BR & G & $C \quad T$ & $T A$ & - & - $A$ & A & G & $A$ & $C$ & $C$ & $A$ & $\mathrm{~T}$ & $C A$ & $A G$ & $A$ & A & G & A & $A C$ & $C A$ & - & - & $\mathrm{GC}$ & $G C$ & G & \\
\hline 1 & Mato Grosso, BR & G & $C \quad T$ & $T A$ & - & $-A$ & A & G & $A$ & $\mathrm{~T}$ & $C$ & $A$ & T & $C A$ & $A G$ & $A$ & A & G & A $A$ & $A C$ & $C A$ & - & - & $C \mathrm{C}$ & $G C$ & & $\pi$ \\
\hline 29 & $\begin{array}{l}\text { Antoquia \& Norte de } \\
\text { Santander, CO }\end{array}$ & A & T T & T $C$ & $C$ & A A & - & - & - & - & - & - & - & $A G$ & $G G$ & $C$ & - & - & - & $-C$ & $C A$ & $\mathrm{~T}$ & $C$ & $C$ & $G C$ & $A$ & A \\
\hline 10 & St Andrews, TR & A & $\mathrm{T} T$ & $T C$ & $C$ & A A & - & - & - & - & - & - & - & $A G$ & $G G$ & $C$ & - & - & - & $-C$ & $C G$ & $\mathrm{~T}$ & C & G & C & A & \\
\hline 124 & $\begin{array}{l}\text { Putumayo \& Caqueta, } \\
\text { CO }\end{array}$ & A & T $\mathrm{T}$ & T A & C & A A & - & - & - & - & - & - & - & & G G & $C$ & - & - & - & $-C$ & $C G$ & - & - & & G C & $G$ & A \\
\hline
\end{tabular}
HXIII $\quad 1$ Madre de Dios, PE A T A A - - G - G C C A T C - - A A G A A T A - G C G G Following primer trim, the ITS2 fragments varied in length from 530-540 bp. In the final 544-bp alignment, 32 sites were found to be variable. $\mathrm{H} 1$ includes specimens of the lectotype series of An. oswaldoi s.s [12].

haplotype with the single specimen sequenced from Amazonas, Brazil (HIII) (Table 2). Haplotype H1 comprises specimens from Espírito Santo and São Paulo, including those in the redescription and lectotype series of An. oswaldoi s.s. [12].

\section{MtDNA COI sequences of An. oswaldoi s.l.}

The mtDNA COI barcode sequences $(n=110,658$ bp without primers) revealed 84 unique haplotypes in the 33 localities sampled (Table 1). The amino acid (AA) reading frame starts at the second base of the primeredited sequences. Protein translations, carried out using the invertebrate mitochondrial code showed no stop codons, indicating that all sequences represent functional protein coding genes.

Meta-population analysis of the COI data set using TCS [33] clearly split the data set into four independent networks (Figure 1): An. oswaldoi s.s., An. oswaldoi A, $A n$. oswaldoi B and $A n$. sp. nr. konderi. This analysis is concordant with the ITS2 haplotypes as follow: $A n$. oswaldoi s.s. [12] (haplotype HI), An. oswaldoi A (named herein) (HII-IX), An. oswaldoi B [18] (HX-XII) and An. sp. nr. konderi (named herein) (HXIII). Although high levels of genetic divergence (0.020) were noted in COI sequences between samples from northern Colombia and Trinidad and Tobago when compared to those from southern Colombia, the TCS analysis showed that these comprised a single species, An. oswaldoi B (Figure 1).
Pairwise $C O I$ sequence comparisons between the groups listed above (TCS network) revealed higher levels of COI divergence between them. Intra-specific divergence ranged from 0.007 in $A n$. oswaldoi s.s. $(\mathrm{n}=12)$, to 0.02 in An. oswaldoi B ( $\mathrm{n}=41)$. Inter-specific COI sequence divergences ranged from 0.038 in the most closely related species, An. oswaldoi s.s. and An. oswaldoi B, to 0.064 between An. oswaldoi A and An. oswaldoi B (Table 3).

Four clusters, corresponding to An. oswaldoi s.s. (Brazil), An. oswaldoi A (Brazil and Colombia), An. oswaldoi B (Colombia, Ecuador and Trinidad and Tobago) and An. sp. nr. konderi (Ecuador, Colombia and Peru), were delineated using the MYC model [41] (Figure 2). The MYC model uses only the unique $C O I$ haplotypes, which detects the transition between species to within-population branching patterns. This analysis also lends support for the separate species status of $A n$. konderi of Sallum from Macapá, Amapá, Brazil (GenBank: KF305833), and its close relationship with $A n$. oswaldoi s.l.

The combined analysis of both COI and ITS2 sequences using MrBayes [36], with the $\mathrm{HKY}+\mathrm{I}+\mathrm{G}$ (HasegawaKishino-Yano + Invariant Sites + Gamma) model, again strongly confirmed that $A n$. oswaldoi s.l. is a complex of at least four species (Figure 3 ). The posterior probability had a value of one, for three clades (An. oswaldoi A, An. oswaldoi $\mathrm{B}$ and $A n$. sp. nr. konderi) and 0.6 in An. oswaldoi s.s. however, bootstrap values fully confirm these four species (An. oswaldoi s.s., An. oswaldoi A, An. oswaldoi B and An. 


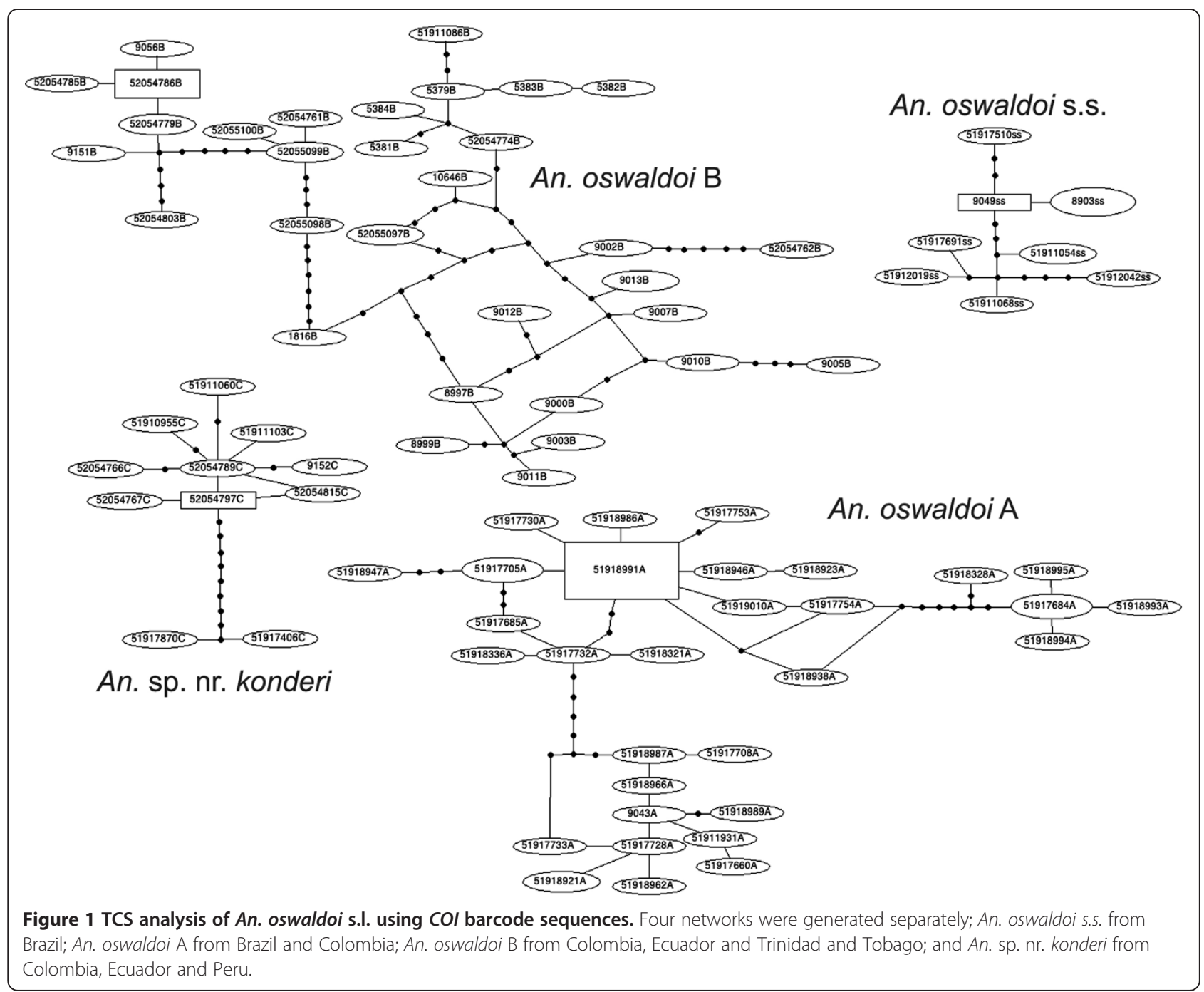

sp. nr. konderi) (Figure 3). The COI sequence of An. konderi of Sallum was found to cluster closely with $A n$. sp. nr. konderi, but these two species are consistently different in four of their ITS2 bases as follows: one transition in position 361 (G/A), two indels (364 (A/-) and $365(\mathrm{~T} /-))$, and one transversion (449 $\mathrm{T} / \mathrm{C}$ ) (data not shown).

Results of the TCS, MYC model and Bayesian analyses using the ITS2 and $\mathrm{COI}$ data sets provides further strong

Table 3 Mean inter- and intra-specific pairwise distances (K2P model)

\begin{tabular}{lccccc}
\hline Species & $\mathbf{n}=$ & osw s.s. & osw A & osw B & sp. $\mathbf{n r}$. kon \\
\hline An. oswaldoi s.s. & 12 & $\mathbf{0 . 0 0 7}$ & & & \\
An. oswaldoi A & 46 & 0.057 & $\mathbf{0 . 0 1 2}$ & & \\
An. oswaldoi B & 41 & 0.038 & 0.064 & $\mathbf{0 . 0 2 0}$ & \\
An. sp. nr. konderi & 11 & 0.045 & 0.053 & 0.056 & $\mathbf{0 . 0 1 0}$ \\
\hline
\end{tabular}

Analyses of $\mathrm{COI}$ sequences separated 110 specimens of Anopheles oswaldoi s.l. into four groups using the TCS model as calculated by Kimura's 2-Parameter distance model (K2P) [35]. support for the following species: An. oswaldoi s.s. from Brazil (Espírito Santo = type locality), Rondônia, Rio de Janeiro and São Paulo); An. oswaldoi A from Brazil (Mato Grosso, Rondônia, Amazonas) and Colombia (Amazonas); An. oswaldoi B from Colombia (Antioquia, Caquetá, Meta, Norte de Santander, Putumayo), Ecuador (Orellana) and Trinidad and Tobago (Valencia); and An. sp. nr. konderi from Colombia (Caquetá), Ecuador (Orellana) and Peru (Madre de Dios, Loreto) (Figures 1, 2, 3 and 4).

\section{Discussion}

\section{$\mathrm{COI}$ and ITS2 sequence analyses}

Based on mitochondrial COI and nuclear ITS2 sequences, this study presents clear molecular evidence that the Oswaldoi-Konderi Complex comprises at least five species: two previously determined (An. oswaldoi s.s. and An. oswaldoi B), as well as An. oswaldoi A and An. sp. nr. konderi, and An. konderi of Sallum defined herein for the first time. Phylogenetic reconstruction of $\mathrm{COI}$ 


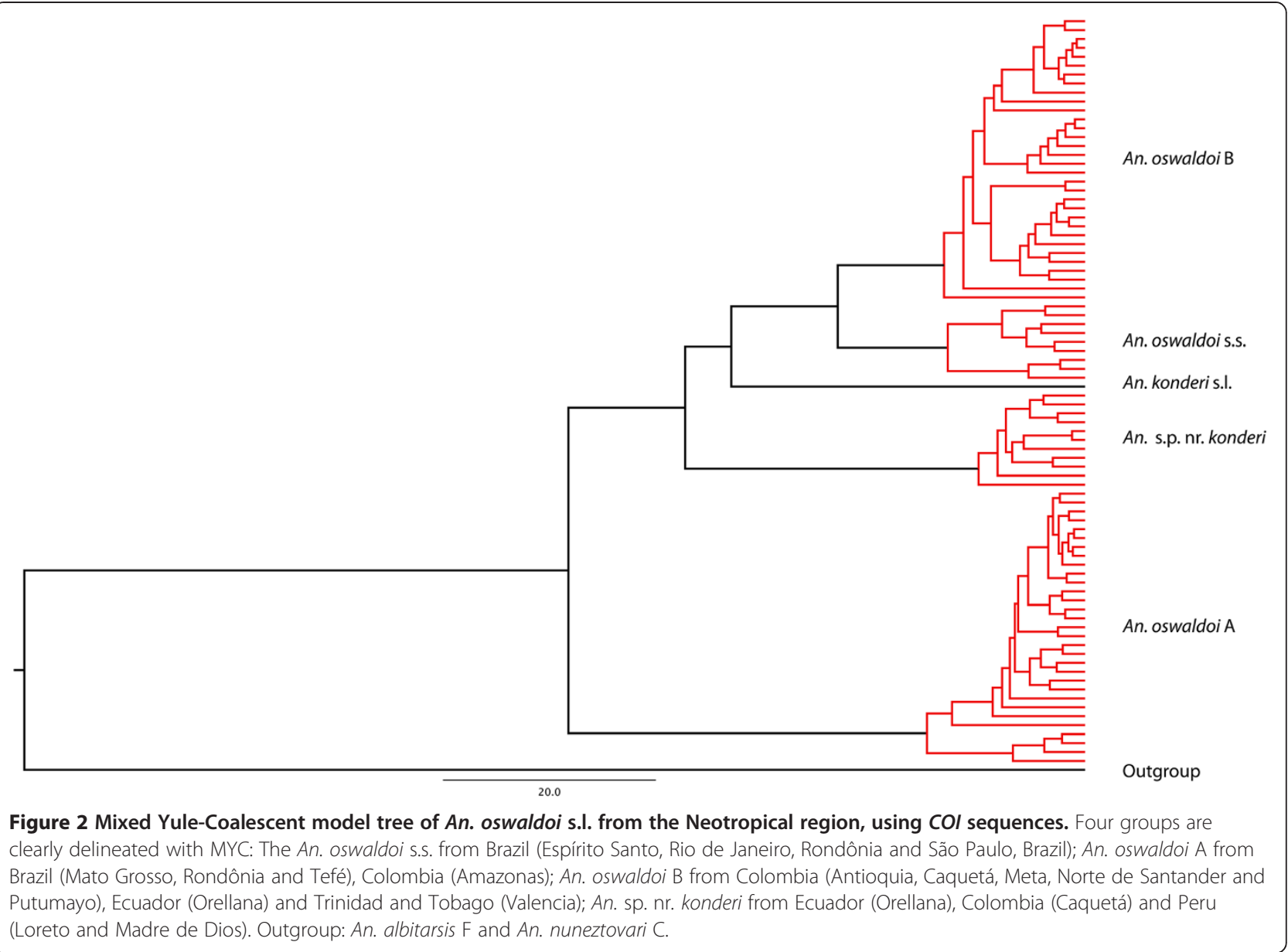

and ITS2 sequences (both independently and concatenated) verified four distinct species, which concur with the MYC and TCS network models. Construction of genealogical networks using TCS are often used to infer evolutionary relationships at the population level; however, identification of independent networks that fall beyond the $95 \%$ parsimony connect limit are considered putative biological species [45]. At this threshold, four independent networks were generated corresponding to the four species listed above (Figure 1). In addition samples of An. konderi of Sallum, initially included as an outgroup in this study, not only represented a separate taxon but also fell firmly within the Oswaldoi Complex in phylogenetic treatments. This supports that An. oswaldoi and An. konderi comprise species complexes of very closely related taxa, which would benefit from being assessed concurrently.

Following this robust molecular delimitation, efforts were made to retrospectively identify samples documented in previously published studies, and relate these to geographical distributions and their regional malaria vector status.

\section{Anopheles oswaldoi s.s.}

Prior to this study, the distribution of "true" An. oswaldoi s.s. had only been determined from Espírito Santo and São Paulo, Brazil [12]. Herein COI data also confirms its presence in the Brazilian States of Rio de Janeiro, Acre (GenBank: DQ784832-35) and Coari (GenBank: DQ784836-38) [15] (Table 4). Ruiz et al. [8,31] suggested a genetic distance threshold of 0.02 for species delimitation in Nyssorhynchus species. Despite the large geographic distance, our An. oswaldoi s.s. from São Paulo and Espírito Santo, Brazil (type locality, south of Brazil) grouped with Scarpassa and Conn's COI sequences [16] from Rondônia State, in the north of Brazil (overall mean K2P distance of 0.010 , range 0.002 to 0.015 ). Given its current distribution, it seems highly likely that An. oswaldoi s.s. could also be present in regions between these Brazilian states, including Mato Grosso, Goias and Minas Gerais, and perhaps even south into Bolivia or Paraguay.

There are no records to suggest that An. oswaldoi s.s. is a vector in the eastern Brazilian provinces of Espírito Santo, Rio de Janeiro or São Paulo. In the north-western 


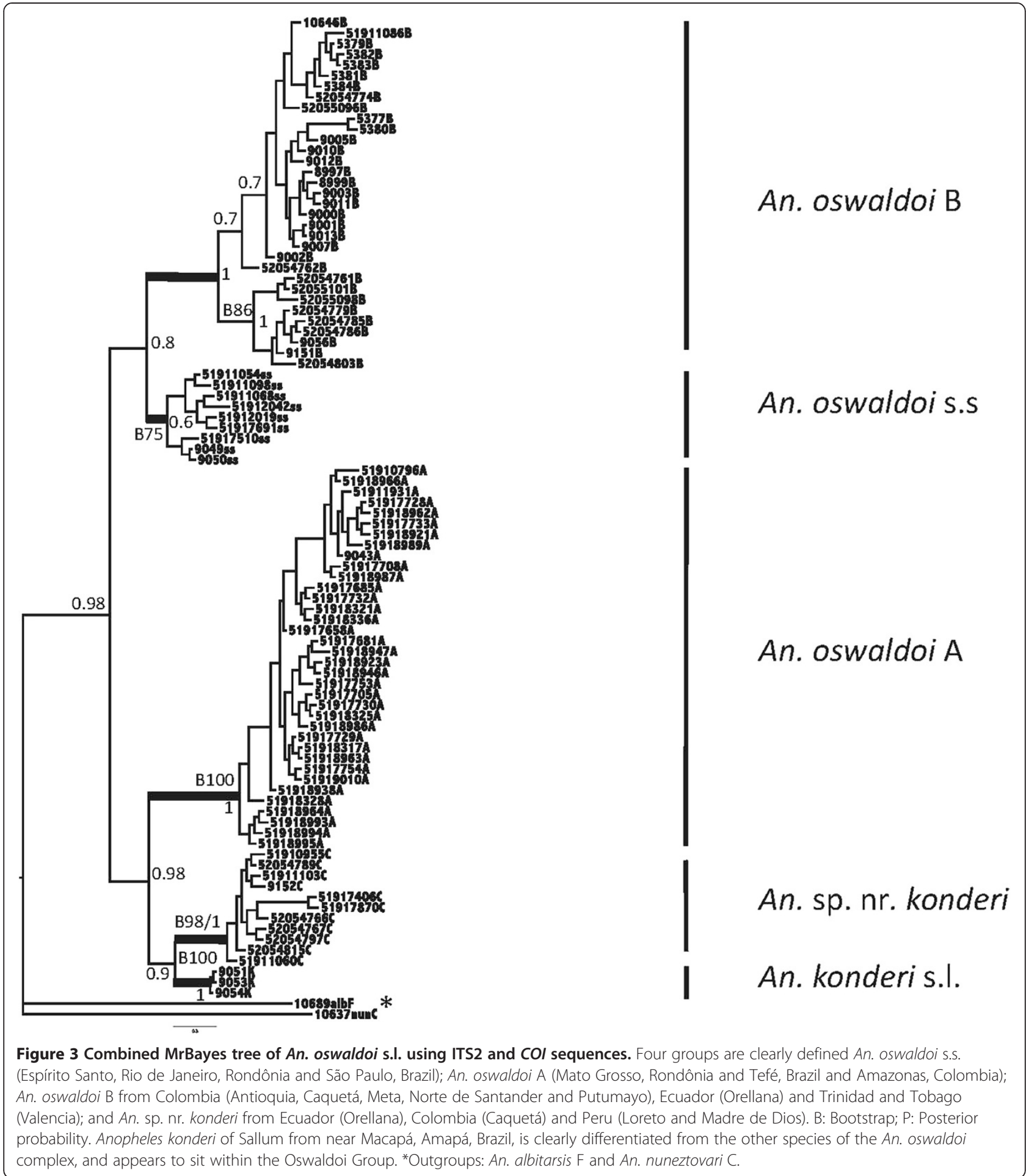

Brazilian state of Rondônia, where An. oswaldoi s.s., An. oswaldoi A and An. sp. nr. konderi are present, de Oliveira-Ferreira et al. [46] and Klein et al. [47,48] reported low levels of Plasmodium infections in what can only be assumed to include a mix of oswaldoi-konderi lineages.

\section{Anopheles oswaldoi B}

In this study, three ITS2 haplotypes [HX, HXI and HXII (Table 2)] were found to be identical to those reported as An. oswaldoi B from Putumayo, Colombia by Ruiz et al. $[17,31]$. These haplotypes shared $99 \%$ identity to published sequences from Ocamo, Venezuela (GenBank: AF055071) 


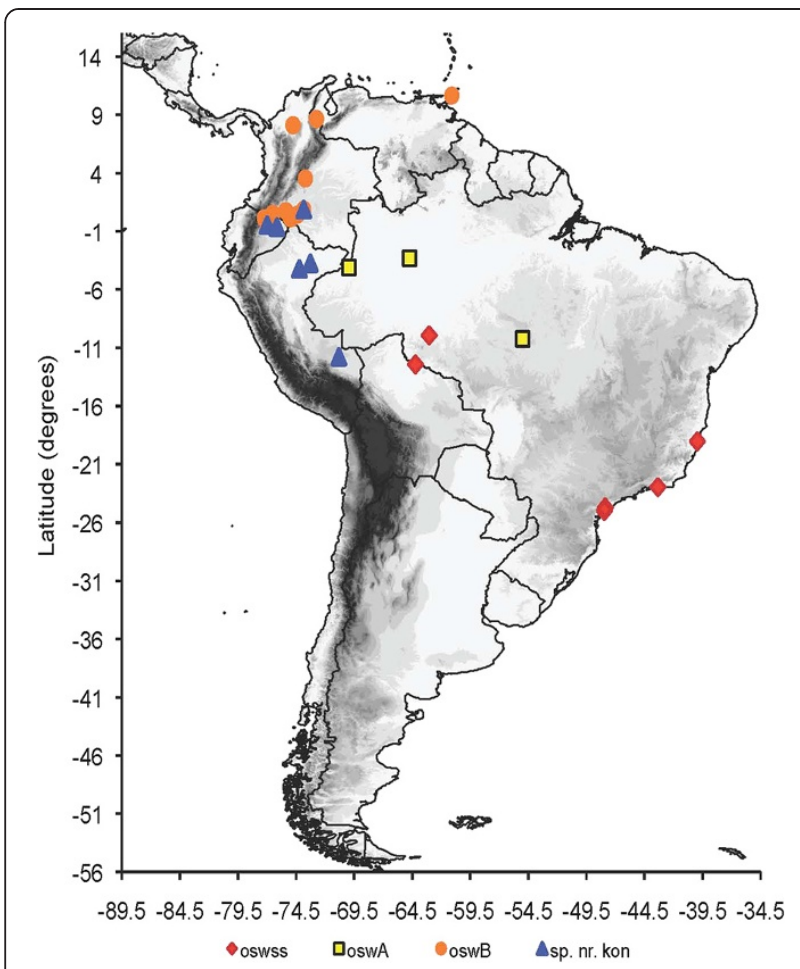

Figure 4 Map showing the overall distribution of An. oswaldoi s.l. in the Neotropical region based on $\mathrm{COI}$ and ITS2 sequences. oswss: An. oswaldoi s.s. (red) in Brazil; oswA: An. oswaldoi A (yellow) in Brazil and Colombia; oswB: An. oswaldoi B (orange) in Colombia, Ecuador and Trinidad and Tobago; and sp. nr. kon: An. sp. nr. konderi (blue) in Colombia, Ecuador and Peru.

and Amapá, Brazil (GenBank: AF056318) (= Group II of Marrelli et al. [14]). Our analyses of both individual and combined COI and ITS2 data sets, grouped the above sequences into a single phylogenetic cluster and TCS network, confirming $A n$. oswaldoi $\mathrm{B}$ as a separate species in the An. oswaldoi complex. This study increases the known distribution of An. oswaldoi B to include the Departments of Antioquia, Caquetá and Norte de Santander (Colombia), and the Province of Orellana (Ecuador) and Saint Andrew/ Saint David (Trinidad and Tobago) (Figure 4).

Plasmodium vivax infection was detected in one molecularly confirmed An. oswaldoi B specimen (of 361 positive mosquitoes) collected in Putumayo, Colombia [13]. However An. oswaldoi s.l. has also been incriminated in Amapá, Brazil [49], as a secondary vector in Venezuela [50] and has been experimentally infected with $P$. vivax in Trinidad and Tobago [51], where only An. oswaldoi B has been identified to date. Correlation of these studies with the known distribution of An. oswaldoi B suggest the potential involvement of this species on malaria transmission is over a much wider region of northern and northeastern South America than originally realised.

Currently, the only valid synonym of $A n$. oswaldoi is $A n$. aquacaelestis Curry, originally described from Panama [52].
The original description differentiates An. aquacaelestis from An. aquasalis, and suggests that this Panamanian species is identical to the species present in Trinidad and Tobago. As An. oswaldoi B is the only species of the An. oswaldoi complex that has been detected in Trinidad and Tobago, it would be prudent to carefully study the type series of $A n$. aquacaelestis, to ensure that our informally designated "An. oswaldoi B" is not in fact An. aquacaelestis, prior to assigning a new name.

\section{Anopheles oswaldoi A (designated herein)}

Comparison of our An. oswaldoi A ITS2 sequences (as haplotypes HII-IX; Table 2) revealed high similarity with three in Marrelli et al. [4] and two in Sallum et al. [9]. Our Haplotype III from Tefé, Amazonas, Brazil and Amazon, Colombia, shares $99.8 \%$ identity with GenBank AF056317 from Amazonas, Brazil (= Group I of Marrelli et al. [14]) and varies by only a single base indel $(-/ \mathrm{T})$ at position 166. Our ITS2 haplotype HII from Mato Grosso, Brazil, is $99.4 \%$ identical to GenBank AF055068 from Acre, Brazil (= Group I of Marrelli et al. [14]) with base substitutions at positions 349 (C/A) and 427 (G/A). Our ITS2 haplotype HVI from Mato Grosso, Brazil, is 98.6\% similar to GenBank AF055069 from Rondônia, Brazil (= Group I of Marrelli et al. [14]), and differs at only one base (position 370; G/A) from EU636802 [9]. Sallum et al. [9] described morphological differences in the male genitalia and ITS2 sequences of An. oswaldoi s.l. from Acrelândia, Acre, Brazil, compared to An. oswaldoi s.s. [12]. Our ITS2 haplotype HIV from Mato Grosso is identical to GenBank EU636809 from Acrelândia, Acre. These results clearly show that the unnamed species of $A n$. oswaldoi s.l. described by Marrelli et al. [14] and Sallum et al. [9] corresponds to our An. oswaldoi A.

The COI sequences generated by Scarpassa and Conn [16] overlapped our barcode region by $404 \mathrm{bp}$. Comparison of their trimmed sequences with our data, revealed sequences from their "Group 3" specimens (GenBank DQ784849-51) from Moju, Pará, Brazil were 99\% identical to those of our An. oswaldoi A, thus confirming that An. oswaldoi A is also present in Pará State (Table 4).

Drawing from our data and correlation with other published works $[9,14,16]$, the known distribution of $A n$. oswaldoi A now includes the Brazilian States of Acre, Amazonas, Mato Grosso, Pará and Rondônia, and the Colombian Department of Amazonas (Figure 4). Vector incrimination studies in Acre, Brazil determined $A n$. oswaldoi as a local vector of malaria [53-56]. As the only confirmed species of the Oswaldoi Complex present in Acre, Brazil, it seems likely that An. oswaldoi A plays a role in malaria transmission in this state, and most probably throughout its distribution. 
Table 4 Retrospective identification of published COI sequences of An. oswaldoi s.l. (DQ784827-DQ784851 [16]) and An. konderi s.l. (JF437965-JF437974 [23]) in relation to species determined herein, through sequence homology

\begin{tabular}{|c|c|c|c|c|c|c|}
\hline Locality (Brazil) & GenBank accession & GenBank identification & osw s.s. & osw A & sp. nr. kon & kon of Sallum \\
\hline \multirow[t]{9}{*}{ Acre, Sena Madureira } & DQ784827 & An. oswaldoi & & & $98 \%$ & \\
\hline & DQ784828 & An. oswaldoi & & & $98 \%$ & \\
\hline & DQ784829 & An. oswaldoi & & & $99 \%$ & \\
\hline & DQ784830 & An. oswaldoi & & & $98 \%$ & \\
\hline & DQ784831 & An. oswaldoi & & & $98 \%$ & \\
\hline & DQ784832 & An. oswaldoi & $99 \%$ & & & \\
\hline & DQ784833 & An. oswaldoi & $99 \%$ & & & \\
\hline & DQ784834 & An. oswaldoi & $99 \%$ & & & \\
\hline & DQ784835 & An. oswaldoi & $99 \%$ & & & \\
\hline \multirow[t]{3}{*}{ Amazonas, Coari } & DQ784836 & An. oswaldoi & $99 \%$ & & & \\
\hline & DQ784837 & An. oswaldoi & $99 \%$ & & & \\
\hline & DQ784838 & An. oswaldoi & $99 \%$ & & & \\
\hline \multirow[t]{10}{*}{ Rondônia, São Miguel } & DQ784839 & An. oswaldoi & & & & $99 \%$ \\
\hline & DQ784840 & An. oswaldoi & & & & $99 \%$ \\
\hline & DQ784841 & An. oswaldoi & & & & $99 \%$ \\
\hline & DQ784842 & An. oswaldoi & & & & $99 \%$ \\
\hline & DQ784843 & An. oswaldoi & & & $100 \%$ & \\
\hline & DQ784844 & An. oswaldoi & & & $99 \%$ & \\
\hline & DQ784845 & An. oswaldoi & & & & $99 \%$ \\
\hline & DQ784846 & An. oswaldoi & & & & $99 \%$ \\
\hline & DQ784847 & An. oswaldoi & & & & $99 \%$ \\
\hline & DQ784848 & An. oswaldoi & & & & $99 \%$ \\
\hline \multirow[t]{3}{*}{ Pará, Moju } & DQ784849 & An. oswaldoi & & $99 \%$ & & \\
\hline & DQ784850 & An. oswaldoi & & $98 \%$ & & \\
\hline & DQ784851 & An. oswaldoi & & $99 \%$ & & \\
\hline Acre, Acrelândia & JF437965 & An. konderi & & & $100 \%$ & \\
\hline \multirow[t]{3}{*}{ Amapá, Macapá } & JF437966 & An. konderi & & & & $100 \%$ \\
\hline & JF437967 & An. konderi & & & & $100 \%$ \\
\hline & $J F 437968$ & An. konderi & & & & $99 \%$ \\
\hline Rondónia, Monte Negro & $J F 437969$ & An. konderi & $99 \%$ & & & \\
\hline \multirow[t]{4}{*}{ Paraná, Porto Natal } & JF437970 & An. konderi & $99 \%$ & & & \\
\hline & $J F 437971$ & An. konderi & $99 \%$ & & & \\
\hline & JF437972 & An. konderi & $99 \%$ & & & \\
\hline & JF437973 & An. konderi & $99 \%$ & & & \\
\hline Paraná, Santa Helena & JF437974 & An. konderi & $99 \%$ & & & \\
\hline
\end{tabular}

[osw s.s.: An. oswaldoi s.s.; osw A: An. oswaldoi A; sp. nr. kon: An. sp. nr. konderi; kon: An. konderi of Sallum from Macapá, Amapá, Brazil].

Anopheles sp. nr. konderi (designated herein)

ITS2 haplotype HXIII was shared by a number of individuals from Madre de Dios and Loreto provinces in Peru, Orellana province in Ecuador, and in the Department of Caquetá, southern Colombia (Figure 4). These sequences showed high similarity (98-100\%) to specimens identified as $A n$. konderi s.l. from Amapá, Brazil [GenBank: JF437934-36, JF437926] [23], differing by only two transitions (G/A, position 361 and $\mathrm{T} / \mathrm{C}$, position 449) and a two base indels (at positions 264-265). We recognize that such intragenetic variation in ITS2 is not uncommon, having also been detected in $A n$. oswaldoi A, An. oswaldoi B and other Nyssorhynchus species [9,57-59]. However, COI sequences from the same individuals analysed by Bayesian, MYC model and TCS network analyses confirm an independent sister cluster to 
the An. konderi of Sallum from Macapá, Amapá, Brazil, also included in our analysis. Both these taxa are unique with respect to a third An. konderi s.l. from Acre reported by Sallum et al. [9] (GenBank: EU636801).

The type locality of An. konderi is Solimões River, Coari, Amazonas, Brazil. However, in their recent redescription of An. konderi, Flores-Mendoza et al. [21] were unable to access material from this locality, using several other localities in Brazil instead. Some samples used in our molecular analysis were the same as those examined by Flores-Mendoza et al. [21], but as the identity of $A n$. konderi is uncertain, we have designated this cluster as An. sp. nr. konderi.

The trimmed 404 bp An. oswaldoi "Group 2" COI sequences of Scarpassa and Conn [16] (GenBank: DQ784827-31 and DQ784843-44) are 98-99\% similar to our An. sp. nr. konderi and 100\% identical to GenBank: JF437965 [16] (Table 4). Correlation of our data with published works confirms the presence of $A n$. sp. nr. konderi in three localities in Brazil (Acrelândia and Sena Madureira (Acre) and São Miguel (Rondônia)), and our data suggest that $A n$. sp. nr. konderi may be allopatric in Madre de Dios and Loreto provinces in Peru, where $A n$. oswaldoi s.l. has been confirmed as an efficient malaria vector [60-62].

The taxonomic status of An. konderi s.l. clearly needs to be reassessed. This and other studies $[9,16,23]$ have provided evidence for at least three species in An. konderi s.l. Concerted efforts are needed to acquire material from the type locality in order to establish the identity of An. konderi s.s. before the systematics of closely related taxa can be properly understood. Given the data presented here, it is likely that the species discussed here will fall into a more comprehensive Oswaldoi-Konderi Complex in future.

\section{Conclusions}

Through novel data and retrospective comparison of COI and ITS2 DNA data, evidence is shown to support three species within of An. oswaldoi s.l. (An. oswaldoi s.s., An. oswaldoi $\mathrm{A}$ and An. oswaldoi $\mathrm{B}$ ), and at least three species in the closely related An. konderi s.l. (An. sp. nr. konderi, An. konderi of Sallum herein, and in Sallum et al. [9]). Determining the specific status and distribution of component members has allowed the circumstantial incrimination of An. oswaldoi A, An. oswaldoi $\mathrm{B}$ and $A n$. sp. nr. konderi as malaria vectors. Anopheles oswaldoi s.s. has never been implicated in malaria transmission. Morphological studies of the species listed in the manuscript are now pertinent, to find reliable diagnostic characters, and to follow with the formal description and naming of the new species determined.

\section{Competing interests}

The authors declare that they have no competing interests.

\section{Authors' contributions}

FRL and YML conceived the ideas; YML, DJP, RCW and MLQ obtained funding; FRL, MLQ, MAMS, CFM, DC, JA, JAO and RCW undertook fieldwork and/or donated samples; FRL, YML and $\mathrm{MH}$ carried out the molecular laboratory work; FRL, YML and RCW carried the data analysis and interpretation; FRL wrote the draft manuscript; YML, RCW, MAMS, DJP, MLQ IDV, CFM, and JA revised the draft manuscript; FRL, RCW and YML carried out the final revision and submitted the manuscript. All authors have read and approved the final version of the manuscript.

\section{Acknowledgements}

This study formed part of the PhD study of FRL conducted at the Natural History Museum, London, and awarded from Canterbury Christ Church University, Canterbury, Kent, U.K. This investigation received financial support from the UNICEF/UNDP/World Bank/WHO Special Programme for Research and Training in Tropical Diseases (TDR) (grant A50252 to YML), Canterbury Christ Church University (studentship to FRL). Additional funding was obtained through the Friends of the Natural History Museum, London to further the activities of the Mosquito Barcoding Initiative (to YML); the Consortium for the Barcode of Life (CBOL) (to YML and RCW) and the Sloane Foundation (to YML and RCW); the National Institute of Health (NIH), USA (grant 2R01AI054139 to Jan E. Conn) and COLCIENCIAS (grant 110134319196 to MLQ). We thank Dr. A. Papadopoulou for help with the MYC analysis and Dr. S. Mahamdallie for helpful suggestions and discussions during preparation of the manuscript.

This manuscript was prepared in part whilst YML held a National Research Council Senior Research Associateship Award at the Walter Reed Army Institute of Research. This research was performed in part under a Memorandum of Understanding between the Walter Reed Army Institute of Research and the Smithsonian Institution, with institutional support provided by both organizations. The material to be published reflects the views of the authors and should not be construed to represent those of the Department of the Army or the Department of Defense.

\section{Author details}

${ }^{1}$ Department of Entomology, National Museum of Natural History, Smithsonian Institution, Museum Support Center, Suitland, MD 20746, USA. ${ }^{2}$ Programa de Estudio y Control de Enfermedades Tropicales (PECET), Facultad de Medicina, Universidad de Antioquia, Medellín, Colombia. ${ }^{3}$ Walter Reed Biosystematics Unit, Smithsonian Institution, Museum Support Center, Suitland, MD 20746, USA. ${ }^{4}$ Department of Geographical and Life Sciences, Canterbury Christ Church University, Kent, UK. ${ }^{5}$ Facultad de Medicina, Universidad Nacional de Colombia, Bogotá, Colombia. ${ }^{6}$ Departamento de Epidemiologia, Faculdade de Saúde Pública, Universidad de São Paulo, São Paulo, SP, Brazil. ${ }^{7}$ Naval Medical Research Unit (NAMRU-6), Lima, Peru. ${ }^{8}$ Department of Life Science, Faculty of Science and Technology, University of the West Indies, St. Augustine Campus, West Indies, Trinidad and Tobago. ${ }^{9}$ Servicio Nacional de Control de Enfermedades Transmitidas por Vectores Artrópodos, Ministerio Salud Publica, Guayaquil, Ecuador. ${ }^{10}$ Walter Reed Army Institute of Research, 503 Robert Grant Avenue, Silver Spring, MD 20910, USA.

Received: 19 November 2012 Accepted: 10 September 2013 Published: 12 November 2013

\section{References}

1. Harbach RE: The classification of genus Anopheles (Diptera: Culicidae) a working hypothesis of phylogenetic relationships. Bull Entomol Res 2004, 94(6):537-553.

2. Bourke BP, Foster PG, Bergo ES, Calado DC, Sallum MA: Phylogenetic relationships among species of Anopheles (Nyssorhynchus) (Diptera, Culicidae) based on nuclear and mitochondrial gene sequences. Acta Trop 2010, 114(2):88-96.

3. Conn J: A genetic study of the malaria vector Anopheles nuneztovari from western Venezuela. J Am Mosq Control Assoc 1990, 6(3):400-405.

4. Marrelli MT, Sallum MA, Marinotti O: The second internal transcribed spacer of nuclear ribosomal DNA as a tool for Latin American anopheline taxonomy: a critical review. Mem Inst Oswaldo Cruz 2006, 101(8):817-832. 
5. Motoki MT, Wilkerson RC, Sallum MA: The Anopheles albitarsis complex with the recognition of Anopheles oryzalimnetes Wilkerson and Motoki, n. sp. and Anopheles janconnae Wilkerson and Sallum, n. sp. (Diptera: Culicidae). Mem Inst Oswaldo Cruz 2009, 104(6):823-850.

6. Rosa-Freitas MG, Lourenço-de-Oliveira R, de Carvalho-Pinto CJ, Flores-Mendoza C, Silva-do-Nascimento TF: Anopheline species complexes in Brazil: current knowledge of those related to malaria transmission. Mem Inst Oswaldo Cruz 1998, 93(5):651-655.

7. Silva-do-Nascimento TF, Lourenço-de-Oliveira R: Diverse population dynamics of three Anopheles species belonging to the triannulatus complex (Diptera: Culicidae). Mem Inst Oswaldo Cruz 2007, 102(8):975-982.

8. Ruiz-Lopez F, Wilkerson RC, Conn JE, McKeon SN, Levin DM, Quinones ML, Povoa MM, Linton Y-M: DNA barcoding reveals both known and nove taxa in the Albitarsis group (Anopheles: Nyssorhynchus) of neotropical malaria vectors. Parasites and Vectors 2012, 5:44

9. Sallum MA, Marrelli MT, Nagaki SS, Laporta GZ, Dos Santos CL: Insight into Anopheles (Nyssorhynchus)(Diptera: Culicidae) species from Brazil. J Med Entomol 2008, 45(6):970-981.

10. Sierra DM, Velez ID, Linton Y-M: Malaria vector Anopheles (Nyssorhynchus) nuneztovari comprises one genetic species in colombia based on homogeneity of nuclear ITS2 rDNA. J Med Entomol 2004, 41(3):302-307.

11. Faran ME: Mosquito studies (Diptera: Culicidae) XXXIV: a revision of the albimanus section of the subgenus Nyssorhynchus of Anopheles. Contr Am Entomol Inst 1980, 15:1-215.

12. Motoki MT, Linton Y-M, Ruiz F, Flores-Mendoza C, Sallum MAM: Redescription of Anopheles oswaldoi (Peryassú, 1922) (Diptera: Culicidae), with formal lectotype designation. Zootaxa 2007, 1588:31-51.

13. Quiñones ML, Ruiz F, Calle DA, Harbach RE, Erazo HF, Linton Y-M: Incrimination of Anopheles (Nyssorhynchus) rangeli and An. (Nys.) oswaldoi as natural vectors of Plasmodium vivax in Southern Colombia. Mem Inst Oswaldo Cruz 2006, 101(6):617-623

14. Marrelli MT, Malafronte RS, Flores-Mendoza C, Lourenço-de-Oliveira R, Kloetzel JK, Marinotti O: Sequence analysis of the second internal transcribed spacer of ribosomal DNA in Anopheles oswaldoi (Diptera: Culicidae). J Med Entomol 1999, 36(6):679-684.

15. Marrelli MT, Floeter-Winter LM, Malafronte RS, Tadei WP, Lourenço-de-Oliveira R, Flores-Mendoza C, Marinotti O: Amazonian malaria vector anopheline relationships interpreted from ITS2 rDNA sequences. Med Vet Entomol 2005, 19(2):208-218

16. Scarpassa VM, Conn JE: Molecular differentiation in natural populations of Anopheles oswaldoi sensu lato (Diptera: Culicidae) from the Brazilian Amazon, using sequences of the $\mathrm{CO}$ gene from mitochondrial DNA. Genet Mol Res 2006, 5(3):493-502.

17. Ruiz F, Quiñones ML, Erazo HF, Calle DA, Alzate JF, Linton Y-M: Molecular differentiation of Anopheles (Nyssorhynchus) benarrochi and An. (N.) oswaldoi from southern Colombia. Mem Inst Oswaldo Cruz 2005, 100(2):155-160.

18. Quiñones ML, Harbach RE, Calle DA, Ruiz F, Erazo HF, Linton Y-M: ariante morfológica de adultos hembras de Anopheles benarrochi (Diptera: Culicidae) en Putumayo, Colombia. Biomedica 2001, 21:351-359.

19. Galvão ALA, Damasceno RG: Anopheles (Nyssorhynchus) konderi nova espécie de Anopheles do vale do Amazonas e considerações sobre as espécies do complexo Tarsimaculatus (Diptera, Culicidae). Folia Clin Biol 1942, 14(5-6):115-135.

20. Lane J: Neotropical culicidae. Universidade de São Paulo 1953, 1:548pp.

21. Flores-Mendoza C, Peyton EL, Wilkerson RC, Lourenço-de-Oliveira R: Anopheles (Nyssorhynchus) konderi Galvão and Damasceno: neotype designation and resurrection from synonymy with Anopheles (Nyssorhynchus) oswaldoi (Peryassú) (Diptera: Culicidae). Proc Entomol Soc Wash 2004, 106:118-132

22. Scarpassa VM: Isozyme similarity in Anopheles oswaldoi sensu lato (Diptera: Culicidae) from the Amazon Region, Brazil. J Med Entomol 2005, 42(3):319-326.

23. Motoki MT, Bourke BP, Bergo ES, Da Silva AM, Sallum MAM: Systematic notes of Anopheles konderi and its first record in Paraná State, Brazil. J Am Mosa Control Assoc 2011, 27(3):191-200.

24. Motoki MT, Dos Santos CLS, Sallum MAM: Intraspecific variation on the aedeagus of Anopheles oswaldoi (Peryassú) (Diptera: Culicidae). Neotrop Entomol 2009, 38(1):890-894.

25. Pinault LL, Hunter FF: New highland distribution records of multiple Anopheles species in the Ecuadorian Andes. Malaria J 2011, 10:236.

26. Foley D: A spreadsheet mapping approach for error checking and sharing collection point data. Biodiv Inform 2011, 7:137-142.
27. Collins FH, Paskewitz SM: A review of the use of ribosomal DNA (rDNA) to differentiate among cryptic Anopheles species. Insect Mol Biol 1996, 5(1):1-9.

28. Linton Y-M, Harbach RE, Chang MS, Anthony TG, Matusop A: Morphological and molecular identity of Anopheles (Cellia) sundaicus (Diptera: Culicidae), the nominotypical member of a malaria vector species complex in Southeast Asia. Syst Ent 2001, 26:357-366.

29. Hebert PDN, Cywinska A, Ball SL, deWaard JR: Biological identifications through DNA barcodes. Proc Biol Sci 2003, 270(1512):313-321.

30. Folmer $\mathrm{O}$, Black $M$, Hoeh W, Lutz R, Vrijenhoek R: DNA primers for amplification of mitochondrial cytochrome c oxidase subunit I from diverse metazoan invertebrates. Mol Mar Biol Biotechnol 1994, 3(5):294-299.

31. Ruiz F, Linton Y-M, Ponsonby DJ, Conn JE, Herrera M, Quiñones ML, Velez ID, Wilkerson RC: Molecular comparison of topotypic specimens confirms Anopheles (Nyssorhynchus) dunhami Causey (Diptera: Culicidae) in the Colombian Amazon. Mem Inst Oswaldo Cruz 2010, 105(7):899-903.

32. Maddison DR, Maddison WR: MacClade: Analysis of Phylogeny and Character Evolution. Sunderland: Sinauer Associates; 2003.

33. Clement M, Posada D, Crandall KA: TCS: a computer program to estimate gene genealogies. Mol Ecol 2000, 9(10):1657-1659.

34. Tamura K, Peterson D, Peterson N, Stecher G, Nei M, Kumar S: MEGA5: molecular evolutionary genetics analysis using maximum likelihood, evolutionary distance, and maximum parsimony methods. Mol Biol Evol 2011, 28(10):2731-2739.

35. Kimura $\mathrm{M}: \mathrm{A}$ simple method for estimating evolutionary rates of base substitutions through comparative studies of nucleotide sequences. J Mol Evol 1980, 16(2):111-120.

36. Nylander J: MrModeltest v2. Program distributed by the author: Evolutionary Biology Center, Uppsala University; 2004

37. Ronquist F, Huelsenbeck JP: MrBayes 3: Bayesian phylogenetic inference under mixed models. Bioinformatics 2003, 19(12):1572-1574.

38. Swofford DL: PAUP*: Phylogenetic Analysis Using Parsimony ( ${ }^{*}$ and Other Methods): Version 4. Sunderland, Massachusetts: Sinauer Associates, Inc.; 2002.

39. Felsenstein J: Confidence limits on phylogenies: an approach using the bootstrap. Evolution 1985, 39:783-791.

40. Fontaneto D, Herniou EA, Boschetti C, Caprioli M, Melone G, Ricci C, Barraclough TG: Independently evolving species in asexual bdelloid rotifers. PLOS Biol 2007, 5(4):e87.

41. Pons J, Barraclough TG, Gomez-Zurita J, Cardoso A, Duran DP, Hazell S, Kamoun S, Sumlin WD, Vogler AP: Sequence-based species delimitation for the DNA taxonomy of undescribed insects. Syst Biol 2006, 55(4):595-609.

42. Yule GU: A mathematical theory of evolution, based on the conclusions of Dr. JC Willis, FRS. Phil Trans Roy Soc London Series B 1925, 213:21-87.

43. Sanderson MJ: r8s: inferring absolute rates of molecular evolution and divergence times in the absence of a molecular clock. Bioinformatics 2003, 19(2):301-302.

44. Rambaut A: FigTree. v1.3.1. ; 2009 (Available for download from http://tree. bio.ed.ac.uk/software/figtree).

45. Sites JW, Marshall JC: Delimiting species: a Renaissance issue in systematic biology. Trends Ecol Evol 2003, 18:462-470.

46. de Oliveira-Ferreira J, Lourenço-de-Oliveira R, Teva A, Deane LM, Daniel-Ribeiro CT: Natural malaria infections in anophelines in Rondônia State, Brazilian Amazon. Am J Trop Med Hyg 1990, 43(1):6-10.

47. Klein TA, Lima JB, Tada MS: Comparative susceptibility of anopheline mosquitoes to Plasmodium falciparum in Rondônia, Brazil. Am J Trop Med Hyg 1991, 44(6):598-603.

48. Klein TA, Lima JB, Tada MS, Miller R: Comparative susceptibility of anopheline mosquitoes in Rondônia, Brazil to infection by Plasmodium vivax. Am J Trop Med Hyg 1991, 45(4):463-470.

49. Povoa MM, Wirtz RA, Lacerda RNL, Miles MA, Warhurst D: Malaria vectors in the municipality of Serra do Navio, State of Amapá Amazon Region. Brazil. Mem Inst Oswaldo Cruz 2001, 96(2):179-184.

50. Rubio-Palis Y, Curtis CF: Biting and resting behaviour of anophelines in western Venezuela and implications for control of malaria transmission. Med Vet Entomol 1992, 6(4):325-334

51. Rozeboom LE: Subspecific variations among neotropical Anopheles mosquitoes, and their importance in the transmission of malaria. American J Trop Med Hy 1942, 22(3):235-255.

52. Curry DP: Some observations on the Nyssorhynchus group of the Anopheles (Culicidae) of Panama. Am J Epidemiol 1932, 15(2):566-572.

53. Branquinho MS, Lagos CBT, Rocha RM, Natal D, Barata JM, Cochrane AH, Nardin E, Nussenzweig RS, Kloetzel JK: Anophelines in the state of Acre, 
Brazil, infected with Plasmodium falciparum, $P$. vivax, the variant $P$. vivax VK247 and P. malariae. Trans R Soc Trop Med Hyg 1993, 87(4):391-394.

54. Branquinho MS, Araujo MS, Natal D, Marrelli MT, Rocha RM, Taveira FAL, Kloetzel JK: Anopheles oswaldoi a potential malaria vector in Acre, Brazil. Trans R Soc Trop Med Hyg 1996, 90(3):233.

55. Marrelli MT, Branquinho MS, Hoffmann EHE, Taipe-Lagos CB, Natal D, Kloetzel JK: Correlation between positive serology for Plasmodium vivax-like/Plasmodium simiovale malaria parasites in the human and anopheline populations in the State of Acre, Brazil. Trans R Soc Trop Med Hyg 1998, 92(2):149-151.

56. Marrelli MT, Honorio NA, Flores-Mendoza C, Lourenço-de-Oliveira R, Marinotti O, Kloetzel JK: Comparative susceptibility of two members of the Anopheles oswaldoi complex, An. oswaldoi and An. konderi, to infection by Plasmodium vivax. Trans R Soc Trop Med Hyg 1999, 93(4):381-384.

57. Fairley TL, Kilpatrick CW, Conn JE: Intragenomic heterogeneity of internal transcribed spacer rDNA in neotropical malaria vector Anopheles aquasalis (Diptera: Culicidae). J Med Entomol 2005, 42(5):795-800.

58. Li C, Wilkerson RC: Intragenomic rDNA ITS2 variation in the neotropical Anopheles (Nyssorhynchus) albitarsis complex (Diptera: Culicidae). J Hered 2007, 98(1):51-59.

59. Onyabe DY, Conn JE: Intragenomic heterogeneity of a ribosomal DNA spacer (ITS2) varies regionally in the neotropical malaria vector Anopheles nuneztovari (Diptera: Culicidae). Insect Mol Biol 1999, 8(4):435-442.

60. Calderón G, Fernández R, Valle J: Especies de la fauna anofelina, su distribución y algunas consideraciones sobre su abundancia e infectividad en el Perú. Revista Peruana de Epidemologia 1995, 8(2):5-23.

61. Hayes J, Calderon G, Falcon R, Zambrano V: Newly incriminated anopheline vectors of human malaria parasites in Junin Department, Peru. J Am Mosq Control Assoc 1987, 3(3):418-422.

62. Guarda JA, Asayag CR, Witzig R: Malaria reemergence in the Peruvian Amazon region. Emerg Infect Dis 1999, 5(2):209-215.

doi:10.1186/1756-3305-6-324

Cite this article as: Ruiz-Lopez et al: Systematics of the Oswaldo

Complex (Anopheles, Nyssorhynchus) in South America. Parasites \& Vectors $20136: 324$

\section{Submit your next manuscript to BioMed Central and take full advantage of:}

- Convenient online submission

- Thorough peer review

- No space constraints or color figure charges

- Immediate publication on acceptance

- Inclusion in PubMed, CAS, Scopus and Google Scholar

- Research which is freely available for redistribution 